\title{
Criterion-Referenced and Norm-Referenced Agreement between the Mile Run/ Walk Test and the One-And-A-Half Mile Run/Walk Test and the Pacer Test
}

\author{
AHMAD HASHIM \\ MOHD SANI MADON \\ Universiti Pendidikan Sultan Idris
}

\begin{abstract}
Purpose - The purpose of this study was to test the reliability of the Mile Run/Walk Test and One- and- a- Half Mile Run or Walk Test, and the PACER Test 20-m, multistage shuttle run using criterionreference and norm reference as a working framework.
\end{abstract}

Method - The sample for the study comprised 2,056 students, with male $(n=1159)$ and female $(n=897)$ randomly selected using stratified random sampling, from the whole population of students aged 13, 14, and 15 years from 18 secondary schools throughout Perak, Malaysia. Two trials of the PACER Test and one each of the Mile Run/Walk Test and One-and-a-Half Mile Run/Walk Test were performed. The estimated criterion referenced reliability for the Mile Run/Walk Test and the One-and-a-Half Mile Run/Walk Test, and the PACER Test was obtained using the proportion of agreement $(\mathrm{Pa})$ and 'modified kappa $(\mathrm{Kq})$ on FITNESSGRAM ${ }^{\circledR}$ Standards (Baumgartner, Jackson, Mahar, \& Rowe, 2003) and the American College of Sports Standards (ACSM, 1999).

Findings - Results of the study showed that the Pacer Test had high reliability for testing the maximum volume of oxygen among male and female students aged 13, 14, and 15 years old. The statistical analysis indicated a positive and strong correlation between test scores and repeated tests for the Pacer Test on male and female students aged 13,14 and 15 years old with $r=0.94$ to $0.97 ; 0.95$ to 0.97 respectively, and was significant $(\mathrm{p}<.05)$.

Value - It is recommended that the PACER Test be used as a component of the Physical Fitness Test battery to replace the Mile Run/Walk Test and the One-and-a-Half Mile Run or Walk Test, which are still used by the Malaysian Ministry of Education, 
Teacher Education Division, Curriculum Development Centre, and also State Education Departments to test students' cardiovascular resistance.

Keywords - Criterion referenced reliability, Norm referenced reliability, Criterion referenced standards

\section{INTRODUCTION}

For each student gaining maturity, an adequate aerobic ability level is normally linked with low levels of heart disease, obesity, diabetes, and hypertension. This problem is chronic and will usually occur during childhood. It is important to stress on education, achievement, and the testing of aerobic ability from an early stage of physical development. It is clear that aerobic ability is important and is accepted as a component of students' fitness test. Physical Education and Sports Science Education teachers as well as school sports coaches can choose from several fitness programmes, including Presidents' Challenge (President's Council on Physical Fitness and Sports) or Prudential FITNESSGRAM ${ }^{\circledR}$ (Baumgartner, Jackson, Mahar \& Rowe, 2003) in order to assess aerobic achievement or cardiovascular ability. However, the FITNESSGRAM fitness programme has been used comprehensively in national teenage fitness programmes and is used by the American Alliance for Health, Physical Education, Recreation and Dance (Safrit, 1995).

All national teenage fitness programmes worldwide at present use criterion reference. This means that a special standard has been set for each test for each age group and gender sex. Subjects are then categorised as having passed if they fulfilled the standard and having failed if they do not achieve the required standard. The criterion referenced standard for FITNESSGRAM was developed to represent the fitness consistency level at the minimum level of adequate health, and minimises health risks (Morrow, Jackson, Disch \& Mood, 1995). The component of the FITNESSGRAM includes aerobic ability, body composition, muscle strength, muscle resistance, and softness. The focus of this research was on the aerobic ability component. Physical Education and Sports Science Education teachers as well as sports coaches who use the FITNESSGRAM have two choices to measure aerobic ability, namely the Mile Run/Walk Test and the PACER Test (Progressive Aerobic Cardiovascular Endurance Run) 20 metre multistage stage shuttle run. The development of 
the standard criterion reference for the Mile Run/Walk Test and the PACER is excellently explained in detail in an article by Cureton (1994).

Carroll (1994) asserted that cardiovascular fitness is one's ability to continuously perform heavy tasks over a lengthy period. It is also known as aerobic fitness, which is the ability of the circulatory and respiratory system to acclimatise and to rejuvenate due to the effect of physical activity such as running, walking fast, cycling, swimming, and others (Nieman, 2003). One can raise one's cardiovascular fitness level and also decrease the risk of heartrelated disease, diabetes, high blood pressure, and certain types of cancer (Larsen, George, Alexender, \& Fellingham, 2002). Pate (1991) reported a consistent relationship between measurement of physical activity, physical fitness, and cardiovascular disease. Using testing and measurement, one can identify someone's level of cardiovascular fitness and suggest suitable exercises for him or her. This can be used to motivate improvement in achievement or to continue a healthy lifestyle, and also can be an early step to detect disease (Miller, 1994).

\section{LITERATURE REVIEW}

Undeniably, varied tests exist to measure cardiovascular fitness. Among them are the Mile Run/Walk Test, the PACER Test (20 Metre Multistage Shuttle Run), 1600 Metre Mile Run/Walk Test, $1 / 4$ Mile Run/Walk Test, 1/2 Mile Run/Walk Test, 3/4 Mile Run/Walk Test, 1.5 Mile Run/Walk Test, Nine- or 12-minute Run/Walk, and other tests. However, none of these tests are consistent and used in all schools in our country. Many physical education and sports science teachers as well as school sports coaches in our country have used the field test approach to measure students' cardiovascular fitness. In truth, we are merely measuring the cardiovascular fitness ability level based on the time taken using minutes and seconds to measure or in metres for the Mile Run/Walk Test, the 1.5 Mile Run/ Walk Test, and the 12-minute Run/Walk. What is certain is that by using the testing approach, we are still unable to know students' real maximum volume of oxygen consumption. The Sports and Health Division, Education Ministry of Malaysia for example, uses the 1500 metre Test in the Basic Physical Fitness Test (Ujian Daya Tenaga Asas or UDTA) as an instrument to measure forms one to five secondary school students' level of cardiovascular fitness. 
A battery test and norm Prudential FITNESSGRAM ${ }^{\circledR}$ as well as a formula to measure the maximum volume of oxygen consumption by ACSM (1999) which is used worldwide by Sports Education practitioners has at least helped to estimate the volume of maximum oxygen consumption based on field tests. Using Prudential FITNESSGRAM ${ }^{\circledR}$ for criterion reference, we can see the extent of Malaysian students' ability level in maximising oxygen consumption. The Mile Run/Walk Test and the One-and-a-Half Mile Run/Walk Test has been used thus far to measure the level of cardiovascular fitness and has been accepted as an instrument that can measure aerobic ability (Vincent, Barker, Clarke, \& Harrison, 1999). Despite this, there is no reference for the Mile Run/Walk Test and the One-and-a-Half Mile Run/Walk Test prepared as VO2 max in our country, unlike the West's popular The Prudential FITNESSGRAM $^{\circledR}$, The President's Challenge, South Carolina Physical Fitness Test, AAHPERD Physical Best, The Chrysler Fund-AAU Physical Fitness Programme, and the AAHPERRD Youth Fitness Test. Similarly, there is no reference for the One-anda-Half Mile Run/Walk in the form of VO2 max, except for the $\mathrm{VO}_{2}$ max calculation formula developed by ACSM (1999). Meanwhile, the PACER Test (20 Metre Multistage Shuttle Run) is the latest field test used to measure $\mathrm{VO}_{2}$ max and is reported to have high reliability in measuring the maximum volume of oxygen consumption (Liu, Plowman, \& Looney, 1992).

Until now, there is no single standardised reference criterion that can be used to measure Malaysian secondary school students' cardiovascular fitness achievement. Therefore in order to gain criterion-referenced and norm-referenced agreement for the Mile Run/ Walk Test, One-and-a-Half Mile Run/Walk Test and the PACER Test, the researchers have used the norm test which was introduced by Prudential FITNESSGRAM ${ }^{\circledR}$ and the American College of Sports Medicine (ACSM, 1999) used worldwide as criteria for reference. Two types of tests that measure aerobic fitness introduced in the FITNESSGRAM were used in this study to measure secondary school students' level of aerobic ability. The tests were the Mile Run/ Walk Test and the PACER Test. Meanwhile students' aerobic ability for the One-and-a-Half Mile Run/Walk were evaluated based on the formula and norm introduced by the ACSM (1999). 


\section{Objectives of the Study}

This study aimed to obtain the criterion referenced and norm referenced agreement between the Mile Run/Walk Test, One-anda-Half Mile Run/Walk Test and the PACER Test among male and female students aged 13, 14, and 15 years. Firstly, the findings of this research would determine the percentage of male and female secondary school students aged 13 years, 14 years, and 15 years in the state of Perak who passed the PACER Test, the Mile Run/ Walk Test, and the Body Mass Index based on the FITNESSGRAM Standard (Baumgartner et al., 2003). Secondly, the findings of this study would determine the percentage of male and female secondary school students aged 13 years, 14 years, and 15 years in the state of Perak who passed the One-and- a-Half Mile Run/Walk Test according to the American College of Sports Medicine standards (ACSM, 1999). Thirdly, the findings of this study would provide feedback on the reliability of the PACER test, which is the 20-metre multistage stage shuttle run. Fourthly, this was to determine the reliability of the Mile Run/Walk Test, One-and-a-Half Mile Run/ Walk Test, and the PACER Test so as to determine which test is the most suitable to measure the cardiovascular endurance among students depending on age and gender sex. Fifthly, the findings of this study would provide useful feedback to Sports Education and sports ecience teachers in Perak on the appropriateness of tests to measure cardiovascular endurance among students depending on age level and gender sex. Sixth, the findings of this study could be used by the Malaysian Ministry of Education, teacher education division, curriculum development centre, and state education departments as useful feedback to improve the sports education and sports science curricular.

A study on the criterion referenced and norm referenced agreement between the Mile Run/Walk Test, One-and-a-Half Mile Run/Walk Test and the PACER Test among male and female secondary school students aged 13 years, 14 years, and 15 years in the state of Perak was conducted to achieve the following objectives. Firstly it was to test the test-retest reliability of the PACER Test, the 20 metres multistage stage shuttle run. Secondly, it was to test the similarity in reliability of the Mile Run/Walk Test, One-and-aHalf Mile Run/Walk Test, and the PACER Test based on the norm referenced and criterion referenced framework. Therefore, this was a study to find out if subjects could be classed as pass or fail when compared with the criterion reference for the Mile Run/Walk Test 
and the PACER Test using the standards set in the FITNESSGRAM (Baumgartner et al., 2003) and the One-and-a-Half Mile Run/Walk Test based on the standards set for the American College of Sports Medicine (ACSM, 1999). Thirdly, this study was to determine the norm referenced reliability for the PACER and the correlation between the Mile Run/Walk Test, One-and-a-Half Mile Run/Walk Test and the PACER Test in order to determine which test was the most suitable to be used in order to measure the cardiovascular endurance among students depending on age and gender sex.

\section{METHODOLOGY}

This section discusses the research methodology and the procedure for the Mile Run/Walk Test, One-and-a-Half Mile Run/Walk Test, and the PACER Test among male and female students aged 13, 14, and 15 years. The first section discusses the research design, followed by the conceptual framework of the research, research sample, research instruments, research procedure, method of data gathering, and also data analysis method. The study used the normative survey research approach. All subjects selected were male and female students aged 13, 14, and 15 years. All data in the study were gathered in the form of nominal scales and ratio via the Mile Run/Walk Test, Oneand-a-Half Mile Run/Walk Test and the PACER Test. Data were analysed with the aid of computer software. Descriptive statistical analysis was used to determine the level of maximum volume of oxygen consumption among male and female students aged 13, 14, and 15 years. The body mass in the conceptual framework of the study was implemented based on the criterion referenced and the standard Prudential FITNESSGRAM ${ }^{\circledR}$ (Baumgartner et al., 2003). Meanwhile, the One-and-a-Half Mile Run/Walk Test was completed based on criterion referenced and norm standards of the American College of Sports Medicine Standards (ACSM, 1999).

Scores on level of maximum volume of oxygen consumption or cardiovascular fitness were obtained via the Mile Run/Walk Test, One-and-a-Half Mile Run/Walk Test, and the PACER Test. Analysis was done using the Pearson Product Moment correlation approach in order to determine the reliability of the Mile Run/Walk Test, One-and-a-Half Mile Run/Walk Test, and the PACER Test. The estimated criterion referenced reliability for the Mile Run/ 
Walk Test and the PACER Test as well as the Body Mass Index were gained via the proportion of agreement $(\mathrm{Pa})$ and modified kappa (Kq), using the FITNESSGRAM Standards (Baumgartner et al., 2003). On the other hand, the estimated criterion referenced reliability of the One-and-a-Half Mile Run/Walk Test was obtained through the proportion of agreement $(\mathrm{Pa})$ and modified kappa $(\mathrm{Kq})$ by using the American College of Sports Standards (ACSM, 1999).

\section{Sample for the Study}

The sample for the study comprised 2,056 students, with male ( $\mathrm{N}$ = 1159) and female $(\mathrm{N}=897)$ students randomly selected from the whole population of students aged 13 years $(\mathrm{N}=681), 14$ years $(\mathrm{N}=$ 696), and 15 years $(\mathrm{N}=678)$ from 18 secondary schools throughout Perak. The sample was selected using the stratified random sampling strategy. The researcher randomly identified six out of nine education districts in Perak, and then randomly selected three secondary schools from each of the selected education districts.

\section{Instruments and Research Procedure}

1) The PACER which was a progressive 20 metres multistage stage shuttle run.

2) Mile Run/Walk Test

3) One-and-a-Half Mile Run/Walk Test

4) The Prudential FITNESSGRAM ${ }^{\circledR}$ (Baumgartner et al., 2003)

5) American College of Sports Medicine standards (ACSM, 1999).

\section{DATA ANALYSIS}

The data obtained were analysed using SPSS for windows for version 11.0. The descriptive statistical approach was used to get the mean, standard deviation, percentage, and percentile range. Additionally, proportion of agreement $(\mathrm{Pa})$ and modified kappa $(\mathrm{Kq})$ were used to show the estimated reliability of the criterion reference using the FITNESSGRAM Standard (Baumgartner et al., 2003). Pearson's Correlation Analysis was used to study the relationship between the Mile Run/Walk Test and One-and-a-Half Mile Run or Walk Test, and the PACER Test for each age group according to gender sex. 
Then the One-way Anova analysis approach was used to see the difference in achievement for each test according to age group and sex.

\section{RESULTS}

Table 1 shows the mean achievement from the Pacer Test based on the number of shuttle runs according to age and gender sex of students. The mean achievement for the number of shuttle runs by male students aged 15 years was higher $($ Mean $=41.74, \mathrm{SD}=11.53)$ compared with male students aged 14 years (Mean $=40.55, \mathrm{SD}=$ 13.20) and males aged 13 years (Mean $=38.03, \mathrm{SD}=10.01)$. By comparison, the mean attained for the number of shuttle runs by female students aged 14 years was higher $($ Mean $=36.68, \mathrm{SD}=$ 10.93) compared with female students aged 15 years (Mean $=35.72$, $\mathrm{SD}=7.94)$ and females aged 13 years $($ Mean $=32.96, \mathrm{SD}=6.93)$.

Table 1

Mean Attained for the Number of Shuttle Runs in the PACER Test According to Age and Sex

\begin{tabular}{lccccr}
\hline Age & \multicolumn{2}{c}{ Male } & \multicolumn{2}{c}{ Gender Sex } \\
\cline { 2 - 3 } \cline { 5 - 6 } & Mean & SD & & Mean & \multicolumn{1}{c}{ SD } \\
\hline 13 years & 38.03 & 10.01 & & 32.98 & 6.93 \\
14 years & 40.55 & 13.20 & & 36.68 & 10.93 \\
15 years & 41.74 & 11.53 & & 35.72 & 7.94 \\
\hline
\end{tabular}

Table 2 shows the mean achievement for maximum oxygen consumption $\left(\mathrm{VO}_{2}\right.$ max $)$ in the PACER test based on age and gender sex of students. The mean achievement by male students aged 15 years was higher $(\mathrm{Mean}=33.03, \mathrm{SD}=4.10) \mathrm{ml} \cdot \mathrm{kg}^{-1} \cdot \mathrm{mean}^{-1}$ compared with male students aged 14 years $(\mathrm{Mean}=32.57, \mathrm{SD}=4.67) \mathrm{ml} \cdot \mathrm{kg}^{-1}$. mean $^{-1}$ and males aged 13 years $($ Mean $=31.07, \mathrm{SD}=3.63) \mathrm{ml} \cdot \mathrm{kg}^{-1}$. mean $^{-1}$. By comparison, the mean achievement by female students aged 14 years was higher $($ Mean $=31.18, \mathrm{SD}=3.91) \mathrm{ml}_{\mathrm{kg}}{ }^{-1} \cdot \mathrm{mean}^{-1}$ compared with female students aged 15 years $($ Mean $=30.86$, SD $=2.91) \mathrm{ml} \cdot \mathrm{kg}^{-1} \cdot \mathrm{mean}^{-1}$ and females aged 13 years $($ Mean $=29.85$, $\mathrm{SD}=2.59) \mathrm{ml} \cdot \mathrm{kg}^{-1} \cdot \mathrm{mean}^{-1}$. 
Table 2

$V O^{2}$ Max Mean Achievement Based on the Pacer Test According to Age and Sex

\begin{tabular}{lccccc}
\hline Age & \multicolumn{2}{c}{ Male } & & \multicolumn{2}{c}{ Fex } \\
\cline { 2 - 3 } \cline { 5 - 6 } & Mean & SD & & Mean & SD \\
\hline 13 years & 31.70 & 3.63 & & 29.85 & 2.59 \\
14 years & 32.57 & 4.67 & & 31.18 & 3.91 \\
15 years & 33.03 & 4.10 & & 30.86 & 2.91 \\
\hline
\end{tabular}

Table 3 shows the mean achievement for maximum oxygen intake $\left(\mathrm{VO}^{2} \max \right)$ based on the Mile Run/Walk Test. The mean achievement by male students aged 14 years was higher $($ Mean $=$ 9.95, $\mathrm{SD}=2.08) \mathrm{ml} \cdot \mathrm{kg}^{-1} \cdot \mathrm{mean}^{-1}$ compared with male students aged 15 years $($ Mean $=9.93, \mathrm{SD}=2.14) \mathrm{ml} \cdot \mathrm{kg}^{-1} \cdot \mathrm{mean}^{-1}$ and males aged 13 years $($ Mean $=9.81, \mathrm{SD}=1.76) \mathrm{ml} \cdot \mathrm{kg}^{-1} \cdot \mathrm{mean}^{-1}$. By comparison, the mean achievement by female students aged 13 years was higher (Mean $=10.92, \mathrm{SD}=1.63) \mathrm{ml} \cdot \mathrm{kg}^{-1} \cdot \mathrm{mean}^{-1}$ compared with female students aged 14 years $($ Mean $=10.88, \mathrm{SD}=2.06) \mathrm{ml} \cdot \mathrm{kg}^{-1} \cdot \mathrm{mean}^{-1}$ and females aged 15 years $($ Mean $=10.76, \mathrm{SD}=1.89) \mathrm{ml} \cdot \mathrm{kg}^{-1} \cdot \mathrm{mean}^{-1}$.

Table 3

VO2 Max Mean Attained for the Mile Run/Walk Test According to Age and Sex

\begin{tabular}{lccccc}
\hline Age & \multicolumn{2}{c}{ Male } & & Sex & \multicolumn{2}{c}{ Female } \\
\cline { 2 - 3 } \cline { 5 - 6 } & Mean & SD & & Mean & SD \\
\hline 13 years & 9.81 & 1.76 & & 10.92 & 1.63 \\
14 years & 9.95 & 2.08 & & 10.88 & 2.06 \\
15 years & 9.93 & 2.14 & & 10.76 & 1.89 \\
\hline
\end{tabular}

Table 4 shows the mean obtained for maximum oxygen intake $\left(\mathrm{VO}_{2} \max \right)$ based on the 1.5 Mile Run/Walk Test. The mean attained by male students aged 15 years was higher (Mean $=15.82$, $\mathrm{SD}=3.25) \mathrm{ml} \cdot \mathrm{kg}^{-1} \cdot \mathrm{mean}^{-1}$ compared with male students aged 13 years $($ Mean $=15.30, \mathrm{SD}=2.192) \mathrm{ml} \cdot \mathrm{kg}^{-1} \cdot \mathrm{mean}^{-1}$ and males aged 14 years $($ Mean $=15.02, \mathrm{SD}=2.92) \mathrm{ml} \cdot \mathrm{kg}^{-1} \cdot \mathrm{mean}^{-1}$. By comparison, the mean attained by female students aged 15 years was higher (Mean $=17.03, \mathrm{SD}=3.43) \mathrm{ml} \cdot \mathrm{kg}^{-1} \cdot \mathrm{mean}^{-1}$ compared with female students aged 13 years $($ Mean $=16.63, \mathrm{SD}=3.47) \mathrm{ml} \cdot \mathrm{kg}^{-1} \cdot \mathrm{mean}^{-1}$ and females aged 14 years $($ Mean $=16.42, \mathrm{SD}=4.45) \mathrm{ml} \cdot \mathrm{kg}^{-1} \cdot \mathrm{mean}^{-1}$. 
Table 4

$V O^{2}$ Max Mean Obtained for the 1.5 Mile Run/Walk Test According to Age and Gender Sex

\begin{tabular}{lccccc}
\hline Age & \multicolumn{2}{c}{ Male } & & \multicolumn{2}{c}{ Sex } \\
\cline { 2 - 3 } \cline { 5 - 6 } & Mean & SD & & Mean & SD \\
\hline 13 years & 15.30 & 2.92 & & 16.63 & 3.47 \\
14 years & 15.02 & 2.92 & & 16.42 & 4.45 \\
15 years & 15.82 & 3.25 & & 17.03 & 3.43 \\
\hline
\end{tabular}

The statistical analysis indicated a positive and strong correlation between test scores and repeated tests for the Pacer test on male and female students aged 13 to 15 years. The result showed that the correlation value between the test and the retest for the PACER Test on male students aged 13, 14, and 15 years was between value $r=0.94$ to 0.97 , and was significant at the $p<0.05$ range. By comparison, the correlation value between the test and retest for the PACER Test on female students aged 13, 14, and 15 years also was between value $r=0.95$ to 0.97 and was significant at the $\mathrm{p}<0.05$ range. Statistical analysis using the Proportion of Agreement approach was used to determine the percentage of male and female students aged 13, 14, and 15 years who could be classed as pass or fail compared with the criterion reference for the Mile Run/Walk Test using the FITNESSGRAM Standard reference (Baumgartner et al., 2003). Table 5 shows that only $57.8 \%$ of male students aged 13 years, $50.9 \%$ of males aged 14 years, and $33.2 \%$ of males aged 15 years passed the Mile Run/Walk Test based on the running time specified by the FITNESSGRAM Standard.

Table 5

Criterion Referenced Reliability of the Mile Run/Walk Test Compared with the FITNESSGRAM Standard Based on Age and Gender Sex

\begin{tabular}{|c|c|c|c|c|c|c|c|c|}
\hline \multirow[t]{3}{*}{ Age } & \multicolumn{4}{|c|}{ Male } & \multicolumn{4}{|c|}{ Female } \\
\hline & \multicolumn{2}{|c|}{ Pass } & \multicolumn{2}{|c|}{ Fail } & \multicolumn{2}{|c|}{ Pass } & \multicolumn{2}{|c|}{ Fail } \\
\hline & Frek & $\%$ & Frek & $\%$ & Frek & $\%$ & Frek & $\%$ \\
\hline 13 years & 225 & 57.8 & 164 & 42.2 & 190 & 65.1 & 102 & 34.9 \\
\hline 14 years & 197 & 50.9 & 190 & 49.1 & 171 & 55.2 & 139 & 44.8 \\
\hline 15 years & 127 & 33.2 & 256 & 66.8 & 156 & 52.9 & 139 & 47.1 \\
\hline
\end{tabular}


Statistical analysis using the Proportion of Agreement approach was used to determine the percentage of male and female students aged 13, 14 and 15 years who could be classed as pass or fail compared with the criterion reference for the PACER Test using the FITNESSGRAM Standard (Baumgartner et al., 2003). Table 6 shows that only $34.2 \%$ of male students aged 13 years, $39.8 \%$ of males aged 14 years, and $21.4 \%$ of males aged 15 years passed the Pacer test based on the running time specified by the FITNESSGRAM standard. By comparison, all 100\% female students aged 13, 14, and 15 years passed the PACER Test based on the running time specified by the FITNESSGRAM Standard.

Table 6

Criterion Referenced Reliability of the Pacer Test Compared with the FITNESSGRAM Standard Based on Age and Gender Sex

\begin{tabular}{|c|c|c|c|c|c|c|c|c|}
\hline \multirow[t]{3}{*}{ Age } & \multicolumn{4}{|c|}{ Male } & \multicolumn{4}{|c|}{ Female } \\
\hline & \multicolumn{2}{|c|}{ Pass } & \multicolumn{2}{|c|}{ Fail } & \multicolumn{2}{|c|}{ Pass } & \multicolumn{2}{|c|}{ Fail } \\
\hline & Frek & $\%$ & Frek & $\%$ & Frek & $\%$ & Frek & $\%$ \\
\hline 13 years & 133 & 34.2 & 256 & 65.8 & 292 & 100 & Frek & $\%$ \\
\hline 14 years & 154 & 39.8 & 233 & 60.2 & 310 & 100 & - & - \\
\hline 15 years & 82 & 21.4 & 301 & 78.6 & 295 & 100 & - & - \\
\hline
\end{tabular}

Statistical analysis using the Proportion of Agreement approach was used to determine the percentage of male and female students aged 13,14, and 15 years who could be classed as pass or fail compared with the criterion reference for the One-and-a-Half Mile Run/Walk Test based on the American College of Sports Medicine Standards (ACSM, 1999). Table 7 shows that only $69.9 \%$ of male students aged 13 years, $74.2 \%$ of males aged 14 years, and $43.1 \%$ of males aged 15 years passed the One-and-a-Half Mile Run/Walk Test based on the running time of the American College of Sports Medicine standard (ACSM, 1999). By comparison $87.0 \%$ female students aged 13 years, $84.8 \%$ females aged 14 years, and $84.1 \%$ females aged 15 years passed the One-and-a-Half Mile Run/Walk Test based on the American College of Sports Medicine Standard (ACSM, 1999). 
Table 7

Criterion Reference Reliability of the One-and-a-Half Mile Run/ Walk Test Compared with the ACSM (American College of Sports Medicine) Standards Based on Age and Gender

\begin{tabular}{|c|c|c|c|c|c|c|c|c|}
\hline \multirow[t]{3}{*}{ Age } & \multicolumn{4}{|c|}{ Male } & \multicolumn{4}{|c|}{ Female } \\
\hline & \multicolumn{2}{|c|}{ Pass } & \multicolumn{2}{|c|}{ Fail } & \multicolumn{2}{|c|}{ Pass } & \multicolumn{2}{|c|}{ Fail } \\
\hline & Frek & $\%$ & Frek & $\%$ & Frek & $\%$ & Frek & $\%$ \\
\hline 13 years & 272 & 69.9 & 117 & 30.1 & 254 & 87.0 & 38 & 13.0 \\
\hline 14 years & 287 & 74.2 & 100 & 25.8 & 263 & 84.8 & 47 & 15.2 \\
\hline 15 years & 165 & 43.1 & 218 & 56.9 & 248 & 84.1 & 47 & 15.9 \\
\hline
\end{tabular}

Statistical analysis using the Proportion of Agreement and Modified Kappa was used to determine the relationship between tests among male and female students aged 13, 14 and 15 years. Table 8 shows the relationship between the PACER Test and the Mile Run/ Walk Test for male students aged 13 years, based on the Proportion of Agreement value $(\mathrm{Pa}=0.64)$ and modified kappa $(\mathrm{Kq}=0.43)$, for male students aged 14 years with a Proportion of Agreement value $(\mathrm{Pa}=0.69)$ and modified kappa $(\mathrm{Kq}=0.38)$, and finally, for male students aged 15 years with a Proportion of Agreement value ( $\mathrm{Pa}$ $=0.76)$ and modified kappa $(\mathrm{Kq}=0.40)$. The relationship between the PACER Test and the Mile Run/Walk Test for female students aged 13 years was based on the Proportion of Agreement value (Pa $=0.65)$ and Modified Kappa $(\mathrm{Kq}=0.38)$, for female students aged 14 years the Proportion of Agreement value was $(\mathrm{Pa}=0.55)$ and Modified Kappa $(\mathrm{Kq}=0.00)$, and finally, for female students aged 15 years the Proportion of Agreement value was $(\mathrm{Pa}=0.53)$ and Modified Kappa $(\mathrm{Kq}=0.00)$.

The relationship between the Mile Run/Walk Test and the One-and-a-Half Mile Run/Walk Test for male students aged 13 years was based on the Proportion of Agreement value $(\mathrm{Pa}=0.61)$ and Modified Kappa $(\mathrm{Kq}=0.38)$, for male students aged 14 years the Proportion of Agreement value was $(\mathrm{Pa}=0.65)$ and Modified Kappa $(\mathrm{Kq}=0.28)$, and for male students aged 15 years the Proportion of Agreement value was $(\mathrm{Pa}=0.73)$ and Modified Kappa $(\mathrm{Kq}=0.44)$. Meanwhile, the link between the Mile Run/Walk Test and the Oneand-a-Half Mile Run/Walk Test for female students aged 13 years was based on the Proportion of Agreement value $(\mathrm{Pa}=0.75)$ and Modified Kappa $(\mathrm{Kq}=0.35)$, for female students aged 14 years the Proportion of Agreement value was $(\mathrm{Pa}=0.69)$ and Modified Kappa 
$(\mathrm{Kq}=0.33)$, and for female students aged 15 years the Proportion of Agreement value was $(\mathrm{Pa}=0.67)$ and Modified Kappa $(\mathrm{Kq}=0.31)$.

The relationship between the One-and-a-Half Mile Run/Walk Test and the Pacer for male students aged 13 years was based on the Proportion of Agreement value $(\mathrm{Pa}=0.54)$ and Modified Kappa $(\mathrm{Kq}=0.19)$, for male students aged 14 years the Proportion of Agreement value was $(\mathrm{Pa}=0.60)$ and Modified Kappa $(\mathrm{Kq}=0.28)$, and for male students aged 15 years the Proportion of Agreement value was $(\mathrm{Pa}=0.74)$ and Modified Kappa $(\mathrm{Kq}=0.43)$. Meanwhile, the relationship between the One-and-a-Half Mile Run/Walk Test and the PACER Test for female students aged 13 years was based on the Proportion of Agreement value $(\mathrm{Pa}=0.87)$ and Modified Kappa $(\mathrm{Kq}=0.00)$, for female students aged 14 years the Proportion of Agreement value was $(\mathrm{Pa}=0.85)$ and Modified Kappa $(\mathrm{Kq}=0.00)$, and for female students aged 15 years the Proportion of Agreement value was $(\mathrm{Pa}=0.84)$ and Modified Kappa $(\mathrm{Kq}=0.00)$.

Table 8

Similarity of Criterion Referenced Reliability between the PACER, the Mile Run and the One-and-a-Half Mile Run

\begin{tabular}{|c|c|c|c|c|c|c|}
\hline \multirow[t]{2}{*}{ Test } & \multicolumn{3}{|c|}{$\begin{array}{l}\text { Male } \\
\text { (Age) }\end{array}$} & \multicolumn{3}{|c|}{$\begin{array}{c}\text { Female } \\
\text { (Age) }\end{array}$} \\
\hline & 13 & 14 & 15 & 13 & 14 & 15 \\
\hline PACER and the Mile Run & $(n=389)$ & $(n=387)$ & $(n=383)$ & $(n=292)$ & $(n=310)$ & $(n=295)$ \\
\hline Proportion of Agreement & 0.64 & 0.69 & 0.76 & 0.65 & 0.55 & 0.53 \\
\hline Modified Kappa & 0.43 & 0.38 & 0.40 & 0.38 & 0.00 & 0.00 \\
\hline $\begin{array}{l}\text { The Mile Run and the } \\
\text { One-and-a-Half Mile Run }\end{array}$ & $(\mathrm{n}=389)$ & $(\mathrm{n}=387)$ & $(n=383)$ & $(n=292)$ & $(\mathrm{n}=310)$ & $(\mathrm{n}=295)$ \\
\hline Proportion of Agreement & 0.61 & 0.65 & 0.73 & 0.75 & 0.69 & 0.67 \\
\hline Modified Kappa & 0.38 & 0.28 & 0.44 & 0.35 & 0.33 & 0.31 \\
\hline $\begin{array}{l}\text { The One-and-a-Half Mile } \\
\text { Run and PACER }\end{array}$ & $(n=389)$ & $(\mathrm{n}=387)$ & $(n=383)$ & $(n=292)$ & $(n=310)$ & $(n=295)$ \\
\hline Proportion of Agreement & 0.54 & 0.60 & 0.74 & 0.87 & 0.85 & 0.84 \\
\hline Modified Kappa & 0.19 & 0.28 & 0.43 & 0.00 & 0.00 & 0.00 \\
\hline
\end{tabular}

\section{CONCLUSION AND DISCUSSION}

Results of the study showed that the PACER Test had high reliability for testing the maximum volume of oxygen among male and female students aged 13 to 15 years. The findings of this study are similar with research findings by Liu et al. (1992) who reported 
multiple reliability for the PACER Test via the test and retest approach, attaining .89 intra-class reliability value for 139 male and female subjects aged between 6 to 16 years (Leger, Mercier, Gadoury, \& Lambert, 1998). As for the Mile Run/Walk Test, the findings showed that only $57.8 \%$ of male students aged 13 years passed and succeeded in completing the run within a time range of 7.00 to 10.00 minutes, $50.9 \%$ male students aged 14 years passed and succeeded in completing the run between 7.00 to 9.30 minutes, and $33.2 \%$ of male students aged 15 years passed and succeeded in completing the run within a time range of 7.00 to 9.00 minutes, the times stipulated by the FITNESSGRAM Standard. By contrast, the percentage of passes among female students aged 13 years who succeeded in completing the run within a time range of 9.00 to 11.30 minutes was $65.1 \%, 55.2 \%$ female students aged 14 years succeeded in completing the run within a time range of 8.30 to 11.00 minutes, $52.9 \%$ female students aged 15 years succeeded in completing the run within a time range of 8.00 to 10.30 minutes, the time determined by the FITNESSGRAM Standard. The results of the study showed that 15 year-old male students' cardiovascular resistance was very weak as $66.8 \%$ of they failed to achieve the passing level determined by the FITNESSGRAM Standard.

As for the Pacer Test, the results of the study showed that only $34.2 \%$ male students aged 13 years passed and succeeded in completing the run between 41 to 72 repetitions. $39.8 \%$ of male students aged 14 years passed and succeeded in completing the run between 41 to 83 repetitions, and $21.4 \%$ of male students aged 15 years passed and succeeded in completing the run between 51 to 94 repetitions based on the repeated runs stipulated by the FITNESSGRAM Standard. Meanwhile, all female students aged 13, 14, and 15 years passed and succeeded in completing the run between 23 to 51 repetitions. The result of the study showed that more than $60 \%$ of male students aged 13,14 , and 15 years failed to pass the level stipulated by the FITNESSGRAM Standard. As for the One-and-a-Half Mile Run or Walk Test, the results of the study showed that only $69.9 \%$ of male students aged 13 years, $74.2 \%$ male students aged 14 years, and $43.1 \%$ male students aged 15 years passed based on the running time stipulated by the American College of Sports Medicine standards (ACSM, 1999). The percentage of passes of female students aged 13 years was $87.0 \%$, for female students aged 14 years was $84.8 \%$, and for female students aged 15 years was $84.1 \%$. The result of the study showed that 15 -year-old 
male students' cardiovascular resistance was very weak as $57 \%$ of them failed to achieve the passing level determined by the American College of Sports Medicine Standards (ACSM, 1999).

The results of the study indicated a relation between the Mile Run/Walk Test and One-and-a-Half Mile Run or Walk Test for male students aged 13 years $(P a=0.61)$ and $(K q=0.38)$, male students aged 14 years $(P a=0.65)$ and $(K q=0.28)$, as well as male students aged 15 years $(P a=0.73)$ and $(K q=0.44)$. There was also a relation between the Mile Run/Walk Test and One-and-a-Half Mile Run or Walk Test for female students aged 13 years $(P a=0.75)$ and $(K q=$ $0.35)$, female students aged 14 years $(P a=0.69)$ and $(K q=0.33)$, as well as male students aged 15 years $(P a=0.57)$ and $(K q=0.31)$. There was also a relation between the One-and-a-Half Mile Run or Walk Test and the PACER Test for male students aged 13 years $(P a=0.54)$ and $(K q=0.19)$, male students aged 14 years $(P a=$ $0.60)$ and $(K q=0.28)$, as well as male students aged 15 years $(P a=$ $0.74)$ and $(K q=0.43)$. There was also a relation between the Oneand-a-Half Mile Run or Walk Test and the PACER Test for female students aged 13 years $(P a=0.87)$ and $(K q=0.00)$, female students aged 14 years $(P a=0.85)$ and $(K q=0.00)$, and female students aged 15 years $(P a=0.84)$ and $(K q=0.00)$.

The amount of maximum oxygen use $\left(\mathrm{VO}^{2} \mathrm{max}\right)$ is one of the best indicators to test aerobic fitness. However, subjects undergoing cardiovascular fitness tests need strong commitment to overcome various obstacles. Important aspects which are obstacles include instruments, a convenient place, and subjects' ability as well as other aspects when undergoing cardiovascular fitness tests, especially one that involves measurement of maximum volume of oxygen consumption. Many researchers who have conducted such studies found several appropriate ways to measure the maximum volume of oxygen consumption. Among them are the Mile Run/Walk Test and One-and-a-Half Mile Run or Walk Test and the PACER Test which have not been tested comprehensively in Malaysia. The results of the study showed that there is a relationship between the Pacer Test and the Mile Run/ Walk Test for male students aged 13 years with the Proportion of Agreement $(\mathrm{Pa}=0.64)$ and Modified Kappa $(\mathrm{Kq}=$ $0.43)$, for male students aged 14 years $(P a=0.69)$ and $(\mathrm{Kq}=0.38)$, and for male students aged 15 years $(P a=0.76)$ and $(\mathrm{Kq}=0.40)$. There is a relationship between the Pacer Test and the Mile Run/ Walk Test for female students aged 13 years $(P a=0.65)$ and $(\mathrm{Kq}=$ $0.38)$, for female students aged 14 years $(P a=0.55)$ and $(\mathrm{Kq}=0.00)$, and for female students aged 15 years $(P a=0.53)$ and $(\mathrm{Kq}=0.00)$. 


\section{RECOMMENDATION}

Based on the results of the study, it is recommended that within the state of Perak, attention needs to be given by all parties responsible for the physical development of secondary school students' cardiovascular fitness. Essentially Physical Education teaching and learning activities be conducted efficiently by emphasising the development of cardiovascular resistance. Similarly, activities for 13,14, and 15 year-olds such as sports curriculum and games should be given serious attention. Physical Education and Sports Science school teachers ought to be more careful in selecting tests that are the most appropriate to measure cardiovascular resistance. It is recommended that teachers use the PACER Test to test students' cardiovascular resistance as it is proven to be appropriate and has very higher test reliability compared with the Mile Run/ Walk Test and the One-and-a-Half Mile Run or Walk Test. It is suggested that the PACER Test can also be used as a component of the Physical Fitness Test battery to replace the Mile Run/Walk Test and the One-and-a-Half Mile Run or Walk Test, which are still used by the Malaysian Ministry of Education, Teacher Education Division, Curriculum Development Centre, and also State Education Departments to test students' cardiovascular resistance.

\section{REFERENCES}

ACSM (1999). ACSM's fitness book. United States of America: Human Kinetics.

Baumgartner, T. A, Jackson, A. S., Mahar, M. T., \& Rowe, D. A. (2003). Measurement for evaluation in physical education \& exercise science (7th ed.). New York: McGraw Hill.

Carroll, B. (1994). Assessment in physical education : A teacher's guide to the issues. London: The Palmer Press.

Cureton, K. J. (1994). Distance running performance tests in children: What do they mean? Journal of Physical Education, Recreation and Dance, 53(8), 64-66.

Larsen, G. E., George, J. D., Alexander, J. L., \& Fellingham, G. W. (2002). Prediction of maximum oxygen consumption from walking, jogging, or running. Research Quarterly for Exercise and Sport, 73 (1), 66-67. 
Leger, L. A., Mercier, D., Gadoury, C., \& Lambert, J. (1998). The multistage 20 meter shuttle run test for aerobic fitness. Journal of Sport Sciences, 6, 93-101.

Liu, N. Y. S., Plowman, S. A., \& Looney, M. A. (1992). The reliability and validity of the 20 meter shuttle test in American students 12 to 15 years old. Research Quarterly for Exercise and Sport, 63(4), 360-365.

Miller, D. K. (1994). Measurement by the physical educator: Why and how. USA: Human Kinetis.

Morrow, J. R., Jackson, A. W., Disch, J. G., \& Mood, D. P. (1995). Measurement and evaluation in human performance. Champaign, IL: Human Kinetics.

Nieman, D.C. (2003). Exercise testing and prescription. A healthrelated approach (5th ed). New York: Mc-Graw-Hill.

Pate, R. R. (1991). Health related measures of children's physical fitness. Journal of School Health, 61, 231-233.

Safrit, M. J. (1995). The validity and reliability of fitness tests for children. A review. Pediatric Exercise Science, 2, 9-28.

Vincent, S. D., Barker, R., Clarke, M., \& Harrison, J. (1999). A Comparison of peak heart rates elicited by the 1-Mile Run/ Walk and the progressive aerobic cardiovascular endurance run. Research Quarterly for Exercice and Sport, 70(1), 75-79. 